\title{
PENGARUH MEDIA TEKS BeRJALAN TERHADAP KETERAMPILAN MEMBACA TEKS BERITA SISWA KELAS UII SMP NEGERI 7 PADANG
}

\author{
SYIFA FAUZIA', AFNITA ${ }^{2}$ \\ Universitas Negeri Padang \\ syifafauzia87@gmail.com', afnita@fbs.unp.ac.id²
}

Pertama Diterima: 10 April 2020

Bukti Akhir Diterima: 29 Juni 2020

\begin{abstract}
Abstrak
Penelitian ini dilatarbelakangi oleh rendahnya kemampuan siswa dalam keterampilan membaca teks berita pada siswa kelas VIII SMP Negeri 7 Padang. Adapun tujuan penelitian ini adalah untuk mengetahui pengaruh keterampilan membaca teks berita menggunakan media dibandingkan tidak menggunakan media. Metode yang digunakan dalam penelitian adalah metode eksperimen. Dalam penelitian ini, metode eksperimen digunakan untuk melihat pengaruh media teks berjalan terhadap keterampilan membaca teks berita siswa kelas VIII SMP Negeri 7 Padang. Media yang digunakan seharusnya sesuai dengan karakteristik materi pelajaran dan diarahkan pada proses pembelajaran yang dipusatkan pada siswa sehingga prestasi siswa dapat meningkat. Salah satu media pembelajaran yang menunjang di dalam pembelajaran membacakan berita adalah dengan menggunakan media teks berjalan. Hasil yang didapat dalam penelitian ini yaitu adanya pengaruh pembelajaran dengan menggunakan media teks berjalan dalam keterampilan membaca teks berita siswa di kelas VIII-H SMP Negeri 7 Padang. Hal ini dibuktikan dengan adanya peningkatan nilai siswa pada waktu pretest total nilai 1.595 dan nilai rata-rata adalah 69,35. Setelah menggunakan media teks berjalan dalam proses belajar di kelas ini, didapat peningkatan hasil pembelajaran siswa pada waktu postest dengan total nilai 1.865 dan nilai rata-rata 81,01 .
\end{abstract}

Kata Kunci: Media Pembelajaran, Keterampilan Membaca, Teks Berita, Media Teks Berjalan

\section{Abstract}

This research is motivated by the low ability of students in reading text news skills in class VIII students of SMP Negeri 7 Padang. The purpose of this study was to determine the effect of reading news text using media rather than using media. The method used in research is an experimental method. In this study, the experimental method was used to see the effect of the running text media on news reading skills of VIII grade students of SMP Negeri 7 Padang. The media used should be in accordance with the characteristics of the subject matter and directed at the learning process that is centered on students so that student achievement can increase. One of the learning media that support in learning to read news is to use the media of walking texts. The results obtained in this study are the influence of learning by using the media of walking texts in reading text news skills of students in class VIII-H of SMP Negeri 7 Padang. This is evidenced by an increase in student scores at the total pretest time of 1,595 and the average value is 69.35. After using the running text media in the learning process in this class, an increase in student learning outcomes at post-test time with a total value of 1,865 and an average value of 81.01 .

Keywords: Learning Media, Reading Skills, News Text, Current Text Media

\section{PENDAHULUAN}

Salah satu aspek keterampilan bahasa adalah keterampilan membaca. Membaca merupakan suatu kegiatan yang dilakukan untuk memperoleh pesan atau ide yang disampaikan oleh penulis melalui sebuah tulisan. Membaca adalah sebuah proses untuk memahami yang dilakukan oleh si pembaca dengan mencontohkan dari teks membuat hipotesis menerima atau menolak ide dan membuat hipotesis baru. 
Nurhadi (2004: 11) menyatakan bahwa hal-hal yang harus diperhatikan untuk meningkatkan keterampilan membaca adalah (a) menyadari adanya berbagai variasi tujuan membaca yang berbeda antara satu kegiatan membaca dengan kegiatan membaca yang lain; (b) selalu merumuskan secara jelas setiap kegiatan membaca; (c) memerlukan berbagai pengembangan strategi membaca yang selaras dengan ragam tujuan membaca; (d) memerlukan latihan membaca dengan berbagai variasi tujuan membaca; (e) menyadari bahwa seseorang yang mempunyai daya baca tinggi akan mampu memanfaatkan teknik membaca yang bervariasi sesuai dengan tujuan membaca yang diinginkan.

Untuk meningkatkan keterampilan membaca siswa dapat diterapkan melalui pembelajaran membaca teks berita. Membaca teks berita merupakan salah satu pembelajaran yang sudah ada dalam pelajaran bahasa Indonesia. Salah satu penerapan tersebut pada tingkat Sekolah Menengah Pertama (SMP) sebagaimana telah terdapat dalam standar isi Kurikulum 2013. Salah satu kemampuan yang harus dimiliki siswa sesuai dengan Kompetensi Dasar (KD) adalah membacakan teks berita.

Membacakan teks berita adalah kegiatan menyampaikan informasi atau kejadian yang bersifat fakta dengan menyaringkan bacaan, sehingga pendengar akan memperoleh informasi yang disampaikan pembaca. Tidak hanya menyaringkan teks bacaan, melainkan dalam membacakan teks berita harus memahami teknik dasar membaca agar setiap kata atau kalimat yang dibacakan terdengar jelas dan makna yang disampaikan jelas. Tujuannya untuk menciptakan suara yang dapat menarik minat pendengarnya. Adapun teknik yang harus dikuasai saat membacakanteks berita, yaitu dengan mengucapkan bunyi bahasa secara lantang dan jelas, tekanan suara teratur, dan pandangan mata tidak selalu terfokus pada teks bacaan.

Berdasarkan wawancara yang dilakukan dengan guru bahasa Indonesia kelas VIII SMP Negeri 7 Padang, peneliti memperoleh informasi bahwa keterampilan membaca berita masih menjadi kendala bagi siswa kelas VIII SMP Negeri 7 Padang. Keterampilan siswa dalam membaca belum seluruhnya mencapai standar yang ditetapkan. Siswa masih mengalami kesulitan dalam membacakan teks berita dan mengingat secara rinci informasi apa yang dibacanya dan perhatian siswa saat dalam pembelajaran membaca masih kurang. Hal tersebut terlihat dari hasil latihan membaca yang diberikan oleh guru. Rata-rata siswa hanya mampu mencapai nilai 60 hingga 79, sementara KKM yang ditetapkan yaitu sebesar 80 .

Salah satu faktor nilai siswa masih berada di bawah KKM adalah media kurang menarik yang digunakan oleh guru dalam proses pembelajaran bahasa Indonesia sehingga siswa merasa bosan, tidak tertarik, kaku, dan tidak termotivasi dalam pembelajaran. Untuk menyikapi hal tersebut guru bahasa Indonesia mempunyai tanggung jawab untuk meningkatkan keterampilan membaca khususnya membaca berita. Untuk meningkatkan keterampilan membaca berita sebaiknya guru menggunakan media pembelajaran yang menarik dan sesuai dengan materi yang akan dikomunikasikan menjadi salah satu alternatif yang bisa dijadikan solusi. Media yang digunakan seharusnya sesuai dengan karakteristik materi pelajaran dan diarahkan pada proses pembelajaran yang dipusatkan pada siswa sehingga prestasi siswa dapat meningkat. Salah satu media pembelajaran yang menunjang di dalam pembelajaran membacakan berita adalah dengan menggunakan media teks berjalan. 
Media pembelajaran adalah alat atau materi lain yang menyajikan bentuk informasi secara lengkap dan dapat menunjang dalam proses pembelajaran. Media yang dimaksud adalah media teks berjalan yaitusatu jenis media yang berupa teks yang ditulis dan membentuk satu kesatuan makna yang dapat bergerak. Media teks berjalan biasanya dapat ditemui dalam sebuah stripfilm. Penggunaannya dalam pembelajaran adalah dengan menggunakan alat bantu lain yaitu dengan menggunakan komputer dan satu unit proyektor.

Menurut Antoe (2009), media teks berjalan (marquee) adalah media pembelajaran yang berupa program HTML untuk membuat teks agar bisa bergerak / berjalan yang merupakan suatu perintah yang dapat kita atur sesuai keinginan. Dari uraian tersebut dapat diketahui bahwa melalui media teks berjalan, seseorang dapat mengatur durasi waktu bacaan yang akan digunakan dan mengatur jumlah kata, kalimat, atau paragraf yang akan ditampilkan dalam bacaan.

Penulis merasa perlu untuk meneliti keterampilan membaca teks berita dengan menggunakan media teks berjalan pada siswa kelas VIII SMP Negeri 7 Padang. Hal ini dilakukan untuk mengetahui pengaruh penggunaan media teks berjalan terhadap keterampilan membaca teks berita. Oleh karena itu, penting dilakukan penelitian dengan judul "Pengaruh Media Teks Berjalan terhadap Keterampilan Membaca Teks Berita".

Berdasarkan penelusuran kepustakan yang telah dilakukan, diketahui bahwa penelitian tentang penggunaan media untuk meningkatkan keterampilan membaca siswa telah dilakukan sebelumnya. Beberapa penelitian terdahulu yang berkaitan dapat dikemukakan sebagai berikut. Hasil penelitian pertama diambil dari tulisan Yesi Makunti (2018) penelitiannya dilaksanakan dalam empat tahap, yaitu perencanaan, tindakan, observasi, dan refleksi. Hasil penelitian menunjukkan adanya peningkatan keterampilan membacakan teks berita dengan metode penampilan melalui media teks berjalan. Peningkatan dapat dibuktikan berdasarkan hasil tes yang dilakukan siswa kelas VIII-H SMP Negeri 2 Tengaran yang meliputi tes siklus I dan tes siklus II. Hasil tes pada siklus I menunjukkan nilai rata-rata klasikal membacakan teks berita sebesar 65,63. Kemudian pada tes siklus II nilai rata-rata klasikal membacakan teks berita mencapai 80,93.Kedua, Penelitian yang dilakukan Esra Parangin-angin (2020) menunjukkan adanya peningkatan keterampilan membaca cepat dengan media teks bergerak siswa kelas IX-1 SMP HKBP Sei Mati Medan. Pada siklus I rerata kecepatan membaca siswa adalah $213 \mathrm{kpm}$, rerata pemahaman ide pokok adalah 64, pemahaman simpulan bacaan adalah 61, kecepatan efektif membaca siswa adalah $136 \mathrm{kpm}$ dengan kategori lambatdan presentase ketuntasan siswa adalah 31\%.Ketiga, Dian Puspita Sari (2017) menunjukkan adanya peningkatan kemampuan membacakan teks berita siswa kelas VIII B SMP Negeri 4 Kepahiang setelah dilakukan pembelajaran membacakan teks berita dengan menggunakan media rekaman video berita.Keempat, Yulia Oktarina (2018) hasil penelitiannya membuktikan bahwa terjadi peningkatan proses pembelajaran membaca cepat dengan media Marquee dengan rata-rata 215,5 atau berada pada kategori sedang dan dengan rata-rata 250,25 atau berada pada kategori cepat.Kelima, NasikhatulHidayahDari data yang diperoleh, tingkat keberhasilan penelitian tindakan kelas terjadi kenaikan antara prasiklus dengan tindakan baik siklus I dan siklus II. Dari pra siklus terjadi peningkatan sebesar $17.85 \%$ untuk hasil pada siklus I pertemuan pertama meningkat menjadi 35.71\% dengan demikian terjadi peningkatan sebesar 17.85\%. Pada tindakan siklus II pertemuan pertama mendapatkan hasil yang sama dengan tindakan pada siklus I pertemuan 
pertama yaitu $35.71 \%$ dan mengalami peningkataan pada siklus II pertemuan kedua yaitu mencapai keberhasilan $82.14 \%$.

Melalui pembelajaran membaca dengan menggunakan media teks berjalan (marquee) diharapkan mampu memecahkan masalah dalam proses pembelajaran membaca dengan menggunakan media teks berjalan, rendahnya keterampilan siswa dalam membaca teks berita, dan diharapkan adanya pengaruh yang diberikan dalam bentuk perubahan sikap dan perilaku siswa ke arah yang lebih positif.

\section{METODE PENELITIAN}

Metode yang digunakan dalam penelitian adalah metode eksperimen. Yusuf (2016:76-77) menyatakan bahwa metode eksperimen merpakan salah satu tipe penelitian yang hasilnya lebih akurat dibandingkan dengan tipe penelitian yang lain dalam menentukan sebab akibat. Dalam penelitian ini, metode eksperimen digunakan untuk melihat pengaruh media teks berjalan terhadap keterampilan membaca teks berita siswa kelas VIII SMP Negeri 7 Padang. Jenis eksperimen yang digunakan dalam penelitian ini adalah quasi experiment (eksperimen semu). Menurut Suryabrata (2015:92) mengemukakan tujuan penelitian eksperimen semu adalah untuk memperoleh informasi yang merupakan perkiraan bagi informasi yang dapat diperoleh dengan eksperimen yang sebenarnya dalam keadaan yang tidak memungkinkan untuk mengontrol dan memanipulasi semua variabel yang relevan. Desain penelitian ini adalah one group-postest design karena dalam penelitian ini desain yang digunakan hanya satu kelompok siswa yang dipilih sebagai sampel penelitian. Populasi dalam penelitian ini adalah siswa kelas VIII SMP Negeri 7 Padang yang terdaftar tahun ajaran 2019/2020 dengan jumlah siswa 264 orang dan terbagi atas 9 kelas. Sampel dalam penelitian ini diambil berdasarkan nilai standar deviasi keterampilan membaca teks berita siswa kelas VIII SMP Negeri 7 Padang dengan teknik purposive sampling sehingga peneliti memilih satu kelas yang akan menjadi sampel, yaitu kelas VIII-H yang berjumlah 23 orang dengan nilai rata-rata 69,35 .

Data dalam penelitian ini dikumpulkan melalui dua langkah, yakni siswa mengerjakan tes awal (pretest). Tes awal (pretest) ini dilakukan pada sasst pembelajaran tanpa menggunakan media teks berjalan. Setelah tes awal (pretest) dilakukan maka tahap selanjutnya melakukan tes akhir (postest) pada hari yang berbeda. Tes akhir (postest) dilakukan dengan terlebih dahulu memberikan treatment kepada siswa dengan menggunakan media teks berjalan. Tes digunakan peneliti untuk mengetahui keterampilan membaca berita siswa sebelum dan sesudah diberikan perlakuan berupa media teks berjalan. Memberikan tes awal (pretest) sebelum diberikan perlakuan dan tes akhir (postest) setelah diberikan perlakuan yang berbeda yaitu berupa media teks berjalan.

\section{HASIL PENELITIAN DAN PEMBAHASAN}

Salah satu penunjang keberhasilan dalam proses keberhasilan pembelajaran adalah pelaksanaan pembelajaran. Salah satu penunjang keberhasilan tersebut yaitu penggunaan media yang tepat. Media alternatif yang digunakan untuk meningkatkan keterampilan membaca adalah media teks berjalan. media teks berjalan ini diharapkan menjadi media pembelajaran membaca yang efektif 
dibandingkan dengan pembelajaran membaca sebe,umnya yang hanya menggunakan teks bacaan biasa sehingga terkesan monoton.

Berdasarkan permasalahan yang telah diuraikan, tujuan dalam penulisan ini yaitu untuk mengetahui pengaruh penggunaan media teks berjalan terhadap keterampilan membaca teks berita. Langkah awal peneliti adalah memberikan tes awal pada (pretest) untuk mengukur kondisi awal siswa kelas VIII-H. Kemudian memberikan seperangkat perlakuan dengan menerapkan pembelajaran menggunakan media teks berjalan. Langkah terakhir memberikan tes yang disebut dengan tes akhir (Postest). Berdasarkan penelitian yang telah dilakukan, peneliti memperoleh data hasil tes membaca teks berita melalui tes awal (pretest) dan test akhir (postest). Proses pembelajaran di kelas VIII-H SMP Negeri 7 Padang terbilang sangat baik, karena siswa SMP Negeri 7 Padang selalu antusias dalam hal kegiatan belajar.

\section{Tingkat Keterampilan Membaca Teks Berita pada Kelas VIII-H Sebelum Menggunakan Media Teks Berjalan}

Sebelum menerapkan media pembelajaran, ada beberapa langkah awal yang dilakukan oleh peneliti, yaitu mengambil data berupa hasil tes kecepatan membaca siswa, hasil pemahaman bacaan siswa melalui tes pilihan ganda sebanyak 15 soal.

Tabel 1. Daftar Nilai Pretest Siswa Kelas VIII.H

\begin{tabular}{|l|l|l|}
\hline No & $\begin{array}{c}\text { Kode } \\
\text { Sampel }\end{array}$ & Pretest \\
\hline 1 & 001 & 75 \\
\hline 2 & 002 & 65 \\
\hline 3 & 003 & 75 \\
\hline 4 & 004 & 65 \\
\hline 5 & 005 & 65 \\
\hline 6 & 006 & 70 \\
\hline 7 & 007 & 70 \\
\hline 8 & 008 & 70 \\
\hline 9 & 009 & 65 \\
\hline 10 & 010 & 70 \\
\hline 11 & 011 & 70 \\
\hline 12 & 012 & 75 \\
\hline 13 & 013 & 65 \\
\hline 14 & 014 & 65 \\
\hline 15 & 015 & 80 \\
\hline 16 & 016 & 70 \\
\hline 17 & 017 & 65 \\
\hline 18 & 018 & 70 \\
\hline 19 & 019 & 70 \\
\hline 20 & 020 & 70 \\
\hline 21 & 021 & 65 \\
\hline 22 & 022 & 65 \\
\hline 23 & 023 & 75 \\
\hline & Jumlah & 1595 \\
\hline & Rata-rata & 69.35 \\
\hline & & \\
\hline
\end{tabular}


Nilai rata-rata hasil pretest pembelajaran membaca teks berita dapat diketahui dengan perhitungan berikut.

$$
\begin{aligned}
& M=\frac{\sum f x}{N} \\
& M=\frac{1.595}{23}=69,35
\end{aligned}
$$

Berdasarkan perhitungan rumus rata-rata pada analisis hasil belajar pada saat sebelum mendapatkan perlakuan membuktikan bahwa peserta didik sebelum mendapat perlakuan mendapatkan nilai rata-rata pretest sebesar 69,35. Nilai tersebut masih di bawah kriteria ketuntasan minimum (KKM) yang telah ditentukan oleh sekolah sebesar $>80$. Berdasarkan data hasil pretest hanya 1 peserta didik yang nilainya telah mencapai KKM, sedangkan 22 peserta didik lainnya masih mendapatkan nilai di bawah KKM.

\section{Tingkat Keterampilan Membaca Teks Berita Pada Kelas VIII-H Setelah Menggunakan}

\section{Media Teks Berjalan}

Data tes akhir ini diperoleh dari hasil belajar Bahasa Indonesia siswa setelah memanfaatkan media teks berjalan dalam proses pembelajaran membaca teks berita. Data tes akhir ini diperoleh memllaui tes kecepatan membaca dengan membaca teks berita pada video yang sudah disediakan. Hasil perolehan nilai tes akhir terdapat dalam tabel di bawah ini.

Tabel 2. Daftar Nilai Pretest Siswa Kelas VIII.H

\begin{tabular}{|l|l|l|}
\hline No & $\begin{array}{c}\text { Kode } \\
\text { Sampel }\end{array}$ & Pretest \\
\hline 1 & 001 & 80 \\
\hline 2 & 002 & 80 \\
\hline 3 & 003 & 80 \\
\hline 4 & 004 & 80 \\
\hline 5 & 005 & 85 \\
\hline 6 & 006 & 80 \\
\hline 7 & 007 & 85 \\
\hline 8 & 008 & 85 \\
\hline 9 & 009 & 85 \\
\hline 10 & 010 & 85 \\
\hline 11 & 011 & 80 \\
\hline 12 & 012 & 75 \\
\hline 13 & 013 & 75 \\
\hline 14 & 014 & 80 \\
\hline 15 & 015 & 80 \\
\hline 16 & 016 & 75 \\
\hline 17 & 017 & 80 \\
\hline 18 & 018 & 85 \\
\hline
\end{tabular}




\begin{tabular}{|l|l|l|}
\hline 19 & 019 & 80 \\
\hline 20 & 020 & 80 \\
\hline 21 & 021 & 85 \\
\hline 22 & 022 & 85 \\
\hline 23 & 023 & 80 \\
\hline & Jumlah & 1865 \\
\hline & Rata-rata & 81.08 \\
\hline
\end{tabular}

Nilai rata-rata postest peserta didik kelas eksperimen setelah diberi perlakuan dengan menggunakan media teks berjalan adalah sebagai berikut.

$$
\begin{aligned}
& \mathrm{M}=\frac{\sum f x}{N} \\
& \mathrm{M}=\frac{1.865}{23}=81,08
\end{aligned}
$$

Nilai rata-rata postest kelas VIII-H setelah diberi perlakuan menggunakan media teks berjalan membuktikan bahwa peserta didik mendapatkan nilai rata-rata di atas kriteria ketuntasan minimum (KKM) yakni sebesar 81,08. Hasil ini meningkat dari hasil nilai rata-rata pretest yang hanya 69,35 . Selain itu jumlah peserta didik yang mendapatkan nilai di atas KKM juga meningkat dari 1 peserta didik menjadi 20 peserta didik dan 3 peserta didik yang masih mendapatkan nilai di bawah KKM.

Berdasarkan hasil perbandingan nilai rata-rata postest pada kelas VIII-H dapat diketahui bahwa pembelajaran membaca teks berita dengan menggunakan media teks berjalan dapat meningkatkan kemampuan membaca peserta didik. Hal tersebut dapat dibuktikan dengan hasil nilai rata-rata postestjauh lebih baik dibandingkan dengan hasil nilai rata-rata pretest.

\section{Pengaruh Media Teks Berjalan terhadap Keterampilan Membaca Teks Berita Siswa Kelas VIII-H SMP Negeri 7 Padang}

Membaca merupakan suatu proses menambah ilmu pengetahuan mengenai sesuatu hal yang dilakukan dalam gagasan yang dituangkan penulis di dalam suatu teks. Hal ini berkaitan dengan yang dikemukakan Tarigan (2010), membaca merupakan salah satu keterampilan berbahasa dari empat keterampilan berbahasa yaitu menyimak, berbicara, membaca, dan menulis.

Kehadiran media menjadi alat yang menunjang keberhasilan pembelajaran. Media pembelajaran juga dapat dipahami sebagai sesuatu yang dapat menyampaikan pesan dais umber agar terciptanya suatu kegiatan belajar secara kondusif sehingga peserta didik dapat menerima proses belajar secara efektif. Dengan demikian, media pembelajaran menjadi penting untuk mrnciptakan proses belajar yang efisien dan efektif. Begitu pula dengan media teks berjalan 
sebagai penunjang proses pembelajaran dalam meningkatkan keterampilan membaca peserta didik dalam pembelajaran teks berita.

Pembelajaran membaca dalam penelitian ini menggunakan media teks berjalan diharapkan dapat meningkatkan pembelajaran membaca. Hal ini bertujuan agar peserta didik lebih mudah dalam membaca teks berita dan juga untuk melatih sikap disiplin peserta didik agar serius dan konsentrasi terhadap bacaan yang akan berpengaruh terhadap hasil belajar peserta didik.

Berdasarkan hasil dari pretest dan postest maka didapat perhitungan statistik sebagai berikut:

Tabel 3. Data Statistik Hasil Nilai Pretest dan Postest Siswa

\begin{tabular}{|c|c|c|}
\hline Test & Jumlah & Rata-rata \\
\hline Pretest & 1595 & 69,35 \\
\hline Posttest & 1865 & 81,01 \\
\hline
\end{tabular}

Dari hasil Tabel 1 dapat disimpulkan bahwa adanya pengaruh pembelajaran dengan menggunakan media teks berjalan dalam keterampilan membaca teks berita siswa di kelas VIIIH SMP Negeri 7 Padang. Hal ini dibuktikan dengan adanya peningkatan nilai siswa, yang mana pada waktu pretest total nilai 1.595 dan nilai rata-rata adalah 69,35. Setelah menggunakan media teks berjalan dalam proses belajar di kelas ini, didapat peningkatan hasil pembelajaran siswa pada waktu postest dengan total nilai 1.865 dan nilai rata-rata 81,01 .

Pembelajaran membaca yang dilakukan dalam dua tahap ini telah mampu meningkatkan keterampilan membaca peserta didik. Keterampilan ini sangat penting bagi peserta didik guna memperoleh informasi yang tepat dalam waktu yang terbilang singkat.

\section{PENUTUP}

Berdasarkan hasil penelitian mengenai pengaruh media teks berjalan terhadap keterampilan membaca teks berita siswa kelas VIII SMP Negeri 7 Padang dapat disimpulkan sebagai berikut.

1. Hasil tingkat pemahaman siswa pada pembelajaran membaca teks berita menggunakan media teks berjalan yang diterapkan pada kelas VIII-H menjadikan siswa lebih termotivasi, karena menarik perhatian serta dapat menumbuhkan minat baca siswa. Siswa dapat secara aktif dan fokus dalam pembelajaran, dan lebih memahami kemampuan dalam membacakan teks berita. Berdasarkan hasil penelitian, membuktikan bahwa dengan menerapkan media teks berjalan ternyata keterampilan membaca teks berita siswa dapat meningkat lebih baik. Hal ini dapat dilihat dari hasil nilai rata-rata setelah perlakuan dan sebelum diberikan perlakuan yaitu sebesar $81,01>69,35$.

2. Terdapat pengaruh media teks berjalan terhadap keterampilan membaca teks berita. Hal itu terbukti dengan nilai baik yang diperoleh siswa pada kelas VIII-H setelah diberi perlakuan dengan nilai rata-rata 81,01 . Sedangkan hasil keterampilan membaca teks berita tanpa menggunakan media teks berjalan tergolong kurang baik yaitu dengan nilai rata-rata 69,35. 
Berdasarkan uraian di atas menunjukkan bahwa perlakuan yang berbeda yang diajarkan di kelas VIII-H dalam pembelajaran menggunakan media teks berjalan dan pembelajaran tanpa menggunakan media teks berjalan. Terbukti bahwa penggunaan media teks berjalandalam pembelajaran membaca teks berita memiliki pengaruh.

Setelah peneliti menganalisis hal-hal yang berkaitan dengan penelitian, peneliti ingin memberikan saran kepada guru, pihak sekolah, dan peneliti lain. Saran tersebut adalah sebagai berikut.

1. Guru disarankan menggunakan media dalam pembelajaran bahasa Indonesia khususnya pembelajaran membaca teks berita, dalam hal ini media yang dimaksud adalah media teks berjalan. Media teks berjalan dapat meningkatkan minat dan semangat peserta didik sehingga peserta didik dapat fokus pada materi pelajaran. Pihak sekolah diharapkan dapat memberikan fasilitas kepada peserta didik dengan menyediakan media pembelajaran sehingga dapat meningkatkan kualitas pembelajaran disekolah.

2. Peneliti lain yang memanfaatkan hasil penelitian ini dapat menjadikan penggunaan media teks berjalan sebagai acuan bagi munculnya penelitian lain yang relevan. 


\section{DAFTAR PUSTAKA}

Antoe. (2009). Membuat Efek Tulisan Berjalan (Marquee). Jakarta: Gramedia.

Hidayah, Nasikhatul, dkk. (2016). "Peningkatan Keterampilan Membaca Teks Berita Menggunakan Teknik Pemodelan Berbantuan Media Audio Visual pada Siswa Kelas VIII MTs Ma’Arif Nu Windusari”. Jurnal Pengajaran Bahasa dan Sastra, 1(2).

Makunti, Y. (2018). "Peningkatan Keterampilan Membacakan Teks Berita dengan Metode Penampilan Melalui Media Teks Berjalan pada Siswa Kelas VIII SMP Negeri 2 Tengaran Kabupaten Semarang”. 1(1), 41-52.

Nurhadi. (2004). Bagaimana Meningkatkan Kemampuan Membaca? Bandung: Sinar Baru Algensindo.

Oktarina, Y, Ramaya, Dewi Harlina. (2018). "Efektivitas Penggunaan Media Marquee dalam Meningkatkan Keterampilan Membaca Memindai Siswa Kelas VI SDN 81/II Muara Bungo". Jurnal Tunas Pendidikan, 1(1).

Perangin angina, Esra. (2020). "Peningkatan Keterampilan Membaca Cepat Dengan Media Teks Bergerak Siswa Kelas Ix-1 Smp HKBP Sei Mati Medan”. Jurnal Bahasa Indonesia Prima, 2(1).

Sari, Dian Puspita. (2017). "Peningkatan Kemampuan Membacakan Teks Berita dengan Menggunakan Media Rekaman Video Berita Di Kelas VIII B SMP Negeri 4 Kepahiang”. Jurnal Pendidikan, Bahasa, Sastra dan Pengajarannya, 15(2).

Suryabrata, S. (2015). Metode Penelitian. Jakarta: PT Raja Grafindo Persada.

Tarigan, Henry Guntur. (2010). Membaca sebagai Suatu Keterampilan Berbahasa. Bandung: Angkasa.

Yusuf, Muri. (2016). Metode Penelitian: Kuantitatif, Kualitati, dan Penelitian Gabungan. Jakarta: PT Fajar Interpratama Mandiri. 